Date of Publication: 30/07/2012

\section{Cunninghamia}

A journal of plant ecology for eastern Australia
The Royal

BOTANIC GARDENS \& Domain Trust

ISSN 0727-9620 (print) • ISSN 2200-405X (Online)

\title{
The pre-colonial distribution of grasslands, woodlands and forests on the Werribee plains, Victoria
}

\author{
Steve J Sinclair* \& Keshia Atchison \\ *Corresponding author, Arthur Rylah Institute for Environmental Research, \\ Department of Sustainability and Environment (DSE), 123 Brown St Heidelberg, Victoria 3084 AUSTRALIA \\ Email: Steve.sinclair@dse.vic.gov.au Telephone: 03) 94508728
}

\begin{abstract}
We use historic plans and recent field observations to reconstruct and describe the former (pre-1750) character and distribution of vegetation on the Werribee Plains, near Melbourne. The primary outcome of this research is a detailed vegetation map. The ecological factors controlling the distribution of trees and open-plains are also discussed. The results show that most of the area was treeless grassland at the time of European settlement (1835). This grassland was broken up by clearly-defined areas of Eucalypt forest, some of which remain. There is, in contrast, little remaining trace of the woodlands of Allocasuarina and Banksia, which we show were once widespread on the plains and stony rises beyond the Eucalypt forest. This work is timely, given the proposal for the creation of two large new reserves in the area, which contain many areas that may be subject to restoration.
\end{abstract}

Keywords: pre-1750, she-oak, sheoke, fire, grassland, pre-settlement vegetation, anthropogenic

Cunninghamia (2012) 12(3): 213-227

doi: 10.7751/cunninghamia.2012.12.017

\section{Introduction}

Natural grasslands and sparsely-treed grassy woodlands once occurred widely in lowland Victoria (Willis 1964, Lunt 1991). Such areas were particularly attractive for graziers, and their distribution influenced the pattern and sequence of European settlement in Victoria during the 1830s and onwards (Batman 1835, Powell 1970, Moloney et al. 2006, Boyce 2011). A long history (now over 175 years) of agricultural use has altered these environments, making ecologically intact examples very rare in Victoria, and many of their resident species threatened. Consequently, they are now important for biological conservation. 'Natural Temperate Grassland of the Victorian Volcanic Plain' is now listed as a 'critically endangered' ecological community under the Commonwealth Government Environment Protection and
Biodiversity Conservation Act 1999 (EPBC Act). Lowland grasslands have suffered similar declines around the world and their conservation is a global challenge (Lunt 1991, Watkinson and Ormerod 2001).

Our understanding of these grassy systems is incomplete. Although we have long understood aspects of their ecology and biological composition (e.g. Sutton 1916-17, Patton 1935, Willis 1964, Stuwe and Parsons 1977, Lunt 1991, Morgan and Lunt 1999), we still lack basic historic information on where grassy systems were located in parts of Victoria. Several recent studies have identified previously unknown or forgotten natural grassland areas, using the historical record or careful analysis of existing vegetation (Cook and Yugovic 2003, Yugovic and Mitchell 2006, Sinclair 2008, McDougall 2008). 
The plains to the immediate west of Melbourne (variously and imprecisely identified as the 'Keilor' or 'Werribee' Plains) are among the best-studied grassland areas in Victoria (e.g. Sutton 1916-7, Geraghty 1971, McDougall 1987, Growth Areas Authority 2010a-d.). They are part of the story of Melbourne's settlement (Moloney et al. 2006, Boyce 2011) and we know from published accounts that vast expanses of this area were treeless at the time of colonisation. For example, Grimes (1803) described the Werribee area from the coast as "grassy plains to the mountains. No trees." John Batman (1835) described "Open plains, as far as the eye can see".
The basic form of the open grassland region of the Werribee Plains is fairly well-known (McDougall 1987), however, the fine detail of vegetation patterns are not well understood. Even the ostensibly treeless plains were apparently not completely treeless. Relict trees of several species still exist in scattered places and many of the early accounts mention pockets of woodland or forest. These fine details of grassland, woodland and forest distribution on the Werribee Plains have gained new interest since the Victorian government proposed the establishment of two large $(15,000$ ha total) grassland reserves between Melton and Little River (Department of Planning and Community Development 2009, Department of Sustainability and Environment 2009a, Figure 1).

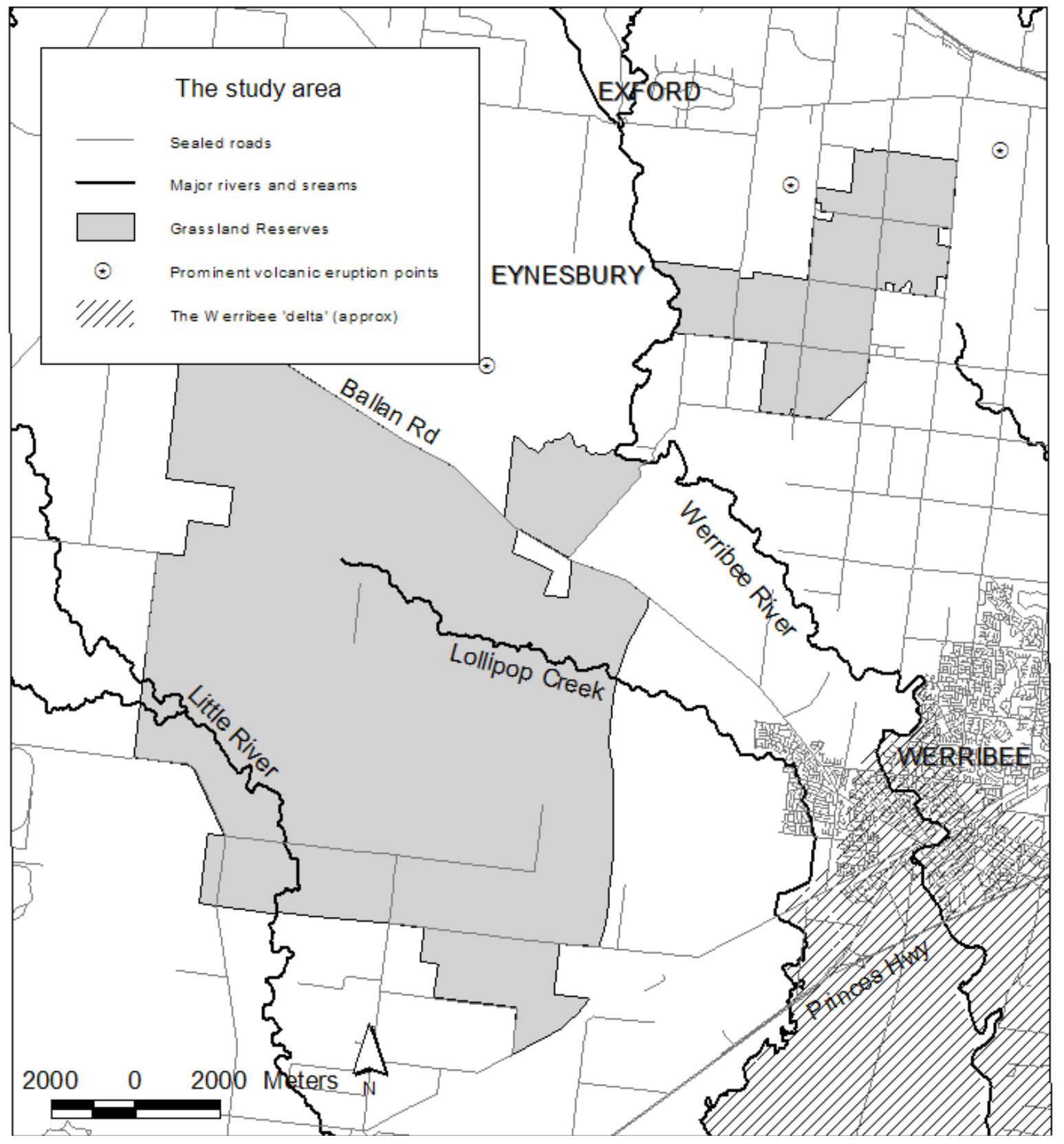

Fig. 1. The Werribee Plains study area west of Melbourne. 
The reserves contain expanses of land that are degraded, and may be subject to restoration. Most restoration efforts try to emulate or re-create what the relevant ecosystem was like before it was degraded (Higgs 1997). In Victoria this involves understanding the character of the vegetation as it was before the abrupt changes caused by the arrival of agriculture in the1830s. Large scale restoration projects - particularly those involving community groups- often include the planting of trees or shrubs; as their establishment produces visible and appealing landscape-scale changes within a few years. Tree planting may, however, be a threat to the ecological integrity of grasslands (Lunt 1991, Baker-Gabb 2002). It is important to re-establish woody vegetation in appropriate location and quantity. The available pre-colonial mapping of the Werribee Plains is not detailed enough to guide restoration; although some resources are excellent for their intended purposes (e.g. McDougall 1987). Our study aimed to produce a pre-colonial vegetation map with sufficient resolution to guide restoration with (or without) woody species. It is the most detailed to date, and uses a broad range of historic and contemporary data sources.

\section{Study area}

The study area was defined arbitrarily around the proposed grassland reserves, being large enough to capture enough of the surrounding landscape to show the context of the vegetation patterns (Figure 1). Rainfall is relatively low

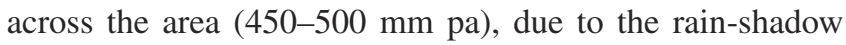
of the Otway Ranges (Jones, 1999). Most of the land surface in the study area is composed of relatively recent lava flows, generally between 4.5 and 2.2 million years old (Stewart 1977, Rosengren 1999, Hare et al. 2005, Gray and McDougall 2009). These form flat or undulating plains. Drainage patterns are irregular and poorly formed, and are still influenced by the paths of the lava flows. Soils are fertile (by Australian standards), shallow and 'heavy' (small particles), with many basalt rocks at or near the surface. Water- or wind-deposited material (parna, sand) from nonvolcanic sources may also occur on the surface (Geraghty 1971, Jones 1999).

Several rivers flow across the area. Some, notably the Werribee, are in deep rocky gorges, cut relatively recently during a period of stream renewal when sea levels were lower than today (Rosengren 1986). The lower Werribee is flanked by the so-called Werribee 'delta', an area that is covered by rich soils deposited by the Werribee and its now-abandoned system of distributaries when the river was not so entrenched (Rosengren 1987). The 'delta' is now used largely for market gardening.

The study area includes the You Yangs in the south west, a range of hills composed of Devonian granite $(364 \mathrm{~m}$ at Flinders Peak). These hills retain their complex patterns of woody vegetation, and are not dealt with in detail here. The study area also includes soils deposited on the beds of lakes and swamps, and an array of places with differing local geologies not dealt with in this overview (such as sedimentary exposures from beneath the basalt plain).

\section{Methods}

Four distinct types of data were collected separately and combined to produce a vegetation map. Firstly, the study area was examined in the field. Relict trees were identified and mapped. The precise positions of the trees (within $\sim 20$ m) were recorded either using a GPS, or by locating the trees on geo-referenced digital aerial photographs. Trees were mostly identified from roadsides using binoculars, or occasionally from gaining access to paddocks. The spatial coverage of this dataset is incomplete and spatially biased (given the idiosyncratic pattern of tree clearance since 1835 and our inability to adequately view all areas). Relict trees are generally distinguishable from planted trees, through some combination of the following: 1) they are of local species rarely planted, 2) they often occur in irregularlyshaped stands across multiple paddocks or as isolated trees away from paddock margins, 3) they often occur in mixed age stands, 4) they are often large or display 'old-growth' forms. Fortunately, the species relevant locally are fairly easy to distinguish from a distance. Trees of doubtful identity were either ignored, or used only to make a distinction between Eucalyptus and Allocasuarina, or to discount absolute treelessness. Where dense stands of trees occurred, a patch was delineated and the main species noted. In a few cases where stands of trees, apparently of a single species, could only be seen in the distance, the air photo was used to guess the coverage of parts of the stand that could not be clearly seen. Several species of tree are very rare locally, and without any evidence that they were once more common, formed no part of the current analysis: Werribee Blue Box Eucalyptus baueriana subsp. thalassina occurs on riparian terraces and a few depressions among Grey Box; White Box Eucalyptus albens occurs very rarely with Grey Box; several Acacia species occur on escarpments, and White Cypresspine Callitris glaucophylla occurs on a few escarpments.

Secondly, we consulted early reports and diary entries to gather descriptive information and illustrations. These sources are cited in the text.

Thirdly, historic plans with information relating to the original native vegetation were retrieved from the microfiche collection at the Public Records Office of Victoria (PROV; this collection is replicated in the State Library). As the plans are not fully catalogued, several sections of the Historic Plans Collection were examined in full (Coastal Surveys 1-171, District Plans 1-87, Features Plans 1-683, Grazing Blocks 1-18, Early Melbourne 1A-128A, Miscellaneous Roll Plans 180-Y104, Pastoral Run Plans 1-1370, Roll Plans 1-1361 Sale Plans A-702, Special Surveys 1-6B, Sydney (prer-1851) A1-Y10). This revealed a number of useful plans, including several not used by McDougall (1987) in his reconstruction. 
Four types of information were extracted from the plans:

1) Forest boundaries. Some plans include line-work showing the boundaries of forests and treeless plains, clearly labelled. These could be directly traced.

2) Annotations on vegetation. Most appear as text, spatially unbounded on the map. These comments help to categorise an area, but not to bound it.

3) Stylised depictions of trees (e.g. stippling). These presumably represent scattered or diffuse patches of trees where no distinct boundary was obvious to the surveyor. These could be 'traced', but only doubtfully. In these cases, aerial photographs and digital elevation data (CSIRO 2010) were used to find on-ground features (rocky rises, wetlands, etc) to guide likely boundaries.

4) Lot corner markers. In the early phase of settlement, lands newly marked for sale or selection were marked in the field by marked trees, cairns, mounds or trenches. Where trees were used, these were identified and their precise position in relation to the lot corner was noted, in terms of a bearing and a distance. Some examples are ambiguous as to whether the bearing is from tree-to-corner or corner-to-tree; no standard method seemed to exist. Fortunately the distances are small (mostly within one chain, i.e. $20.12 \mathrm{~m}$ ), and we assumed that trees were located at the lot corner. In most cases the cadastral boundaries have remained unchanged since the original survey, so re-locating the corners was a trivial task. Importantly, corner marks also revealed areas that were treeless or sparsely treed. Earth marks or cairns were only used when no substantial tree was nearby, certainly not within a chain (this is evidenced by the comment 'no tree near' which is used frequently when an earth mark or cairn is used).

Fourth, digital ortho-aerial photographs $(2007,2009)$ were examined carefully to identify clues in the colour of the soil and the presence of rocks. Wetlands and creeks were mostly identified in this way (visible as greyish patches). We also examined historic aerial photographs, but found they did not significantly add to the information gained from other sources.

The information was combined using a Geographic Information System (GIS, Arcview 3.2, ESRI). Most plans were geo-rectified (digitally stretched into alignment with a base map, Arcview 3.2 \& ImageWarp 2.0) so their features could be traced directly. Information from other plans was recorded 'by eye', in cases where geo-rectification was not practical (e.g. due to too few reference points).

The following principles were used to guide decisions where the evidence was equivocal:

The default type was treeless grassland; assigned wherever there was no evidence for trees or a wetland. This reflects the fact that this map is designed to assist revegetation, and considers inappropriate tree-planting in former grassland to be less desirable than a missed opportunity to plant trees.

Wetlands within a treed area were considered to be Treed Wetlands. Other wetlands were considered treeless, unless there was positive evidence of trees.

Existing stands of relict trees took precedence over the information on plans. The boundaries shown on the plans were often close to the existing tree boundary, in which cases the boundaries were shifted slightly by hand.

Isolated relict trees that did not form part of a treed area recorded on the historic plans were enclosed within a circle of $50 \mathrm{~m}$ radius, and assigned to a type based on the species. The surrounding area remained treeless.

The Victorian Government currently describes vegetation according to Ecological Vegetation Classes (EVCs, Woodgate et al. 1994). An EVC encompasses areas of vegetation (one or more floristic communities) that show consistent form, context in the landscape, and ecological function. The historic record does not, however, always align neatly with this system, and EVCs are here only used as secondary descriptors of the vegetation. The main typology employed here is simple (see below), and was formed by the constraints of the available evidence. The words 'forest' and 'woodland' are used loosely throughout this paper, often as they appear on the primary sources, without strict reference to cover or height thresholds. There is no way of knowing with any precision what the tree density was in most places.

Riparian and escarpment vegetation is not addressed in any detail here. These vegetation types are patterned too finely to be resolved at the scale of this investigation, and remain sufficiently intact for contemporary surveys to discern their character. These vegetation types are shown on the map (Figure 2) in the same style as "treed wetlands". Similarly, the 'delta' is not treated here, as it does not fall within the grassland reserve areas, and is poorly represented in historical sources. As well the 'delta' has been severely altered by a long history of development (market gardening, urbanisation and the Western Treatment Plant).

\section{Results}

\section{The vegetation}

The results of our research are synthesised to create a map showing a reconstruction of the vegetation patterns on the Werribee Plains before colonisation (Figure 2). Figure 3 shows the evidence base used to construct the map. Several distinct types of vegetation were distinguishable.

Forest dominated by Grey Box Eucalyptus microcarpa. Early records make it clear that forest areas were quite distinct from grasslands, and most early surveyors were prepared to draw confident boundaries on the forest patches (Anon 1838, Darke 1839a, b, c, 1840, 1841, before 1858, Hoddle 1850). Hovell (1824, in Moloney et al. 2006) described 


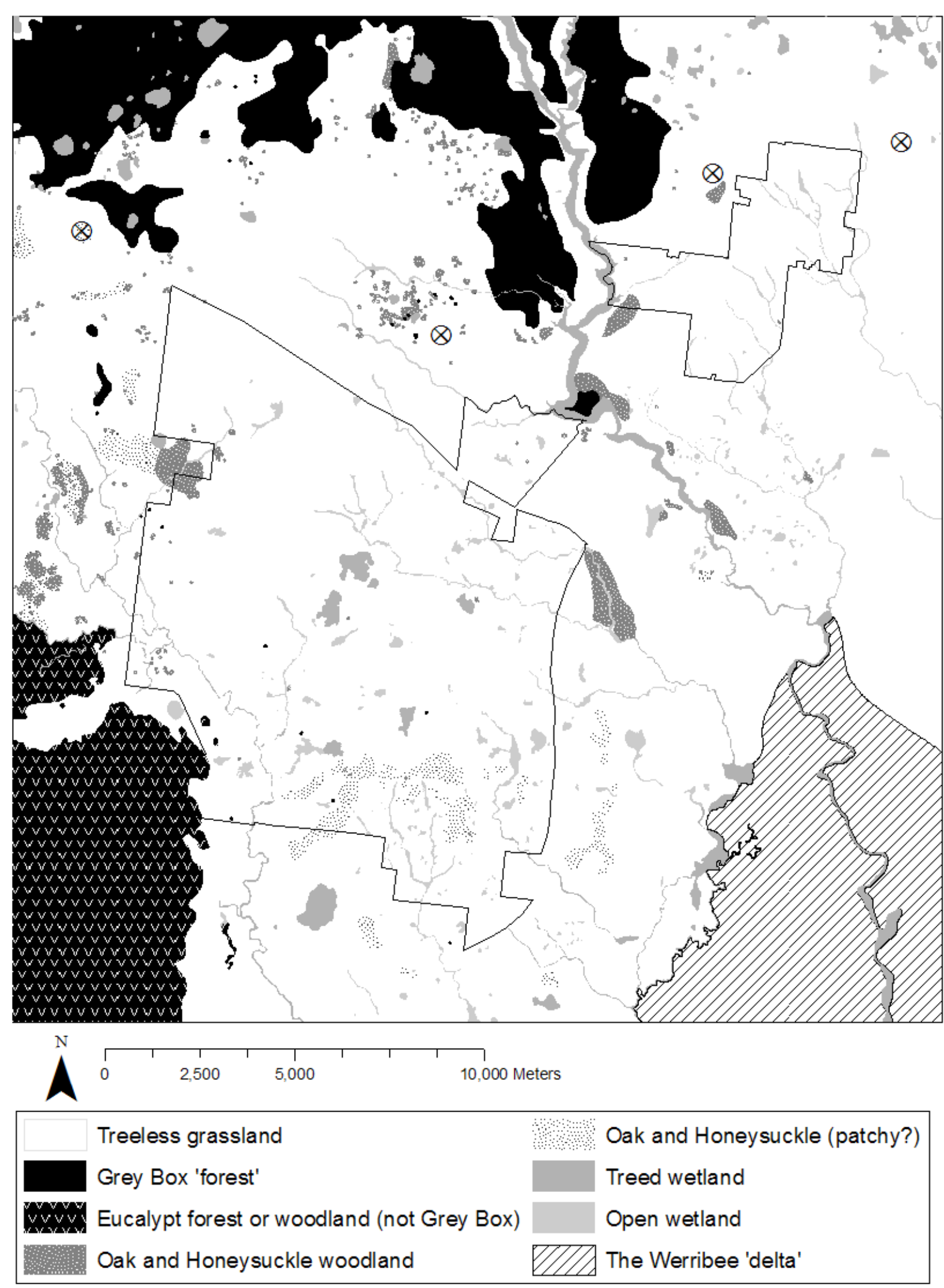

Fig. 2. Reconstruction of pre-colonial vegetation patterns on the Werribee Plains. The crossed circles represent prominent volcanic eruption points. 


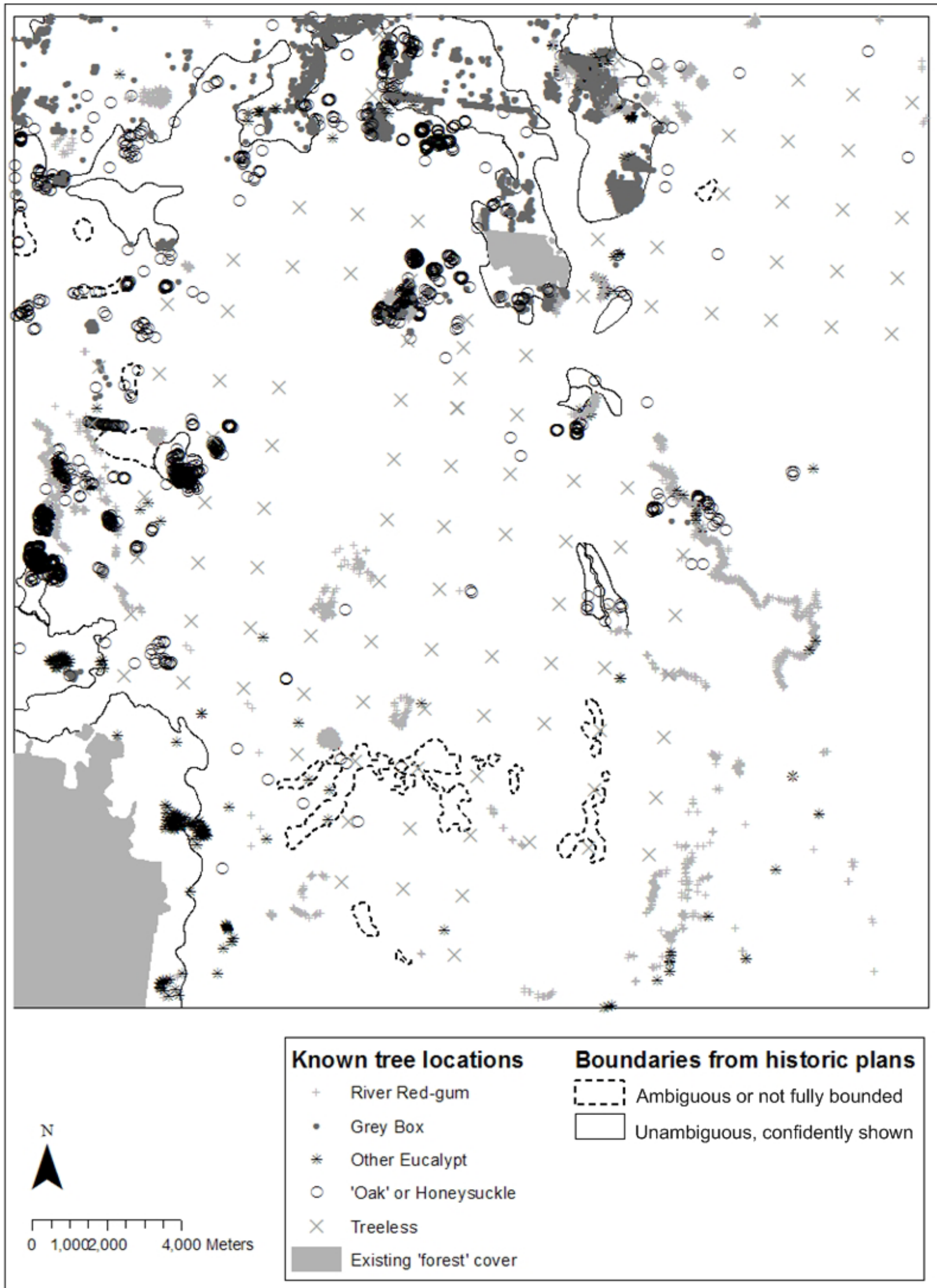

Fig. 3. Summary of the evidence used to construct the map. 
areas near Melton with "patches of forests which appear to separate one plain from another", and noted "it is all plains and small forests". Remnants of these 'small forests' remain in relatively intact form at Eynesbury and Pinkerton, allowing their character to be seen first hand (e.g. Geraghty 1971, Ashby et al. 2007). Although they occur on basalt, the forests show obvious affinities with northern Victoria, highlighting the fact that the Werribee Plains are an outlier of relative aridity south of the Dividing Range (Jones 1999). The forests are strongly dominated by Grey Box Eucalyptus microcarpa (described in some early sources as 'Peppermint'), with occasional specimens of other trees (e.g. Yellow Box Eucalyptus melliodora, Buloke Allocasuarina luehmannii). Shrubs are moderately common, above a sparse grassy layer composed largely of Spear-grasses and Wallaby-grasses (Austrostipa spp. and Rytidosperma spp.). Several early reports commented on the sparse ground layer. Wedge (1835) noted "there is not much grass in the forest". Hoddle (1850) was the most emphatic, describing the Eynesbury forest as "...wholly destitute of grass." These forests are described as 'Plains Woodland' under the current EVC vegetation typology (Oates and Taranto 2001, Ashby et al. 2007). This vegetation type was virtually absent from the grassland reserves, and should not be the target of restoration within their boundaries. Grey Box Forest is shown in Figure 4.

Eucalypt forest or woodland not dominated by Grey Box. Forests or Woodlands of Red Box Eucalyptus polyanthemos and other species cover the eastern slopes of the You Yangs, the granite hills in the west of the study area. These are fairly intact, their character remains evident, and they will not be described further here. Interestingly, however, Red Box trees extended off the granite, and onto the basalt plain in some places (along with Yellow Box Eucalyptus melliodora and Yellow Gum Eucalyptus leucoxylon subsp. connata). We could find no reference to these treed areas in written historic accounts, and historic plans show only minor incursions of forests or woodlands onto the basalt plain around the You Yangs (Darke 1841, Colbert 1855). Scattered but numerous relict trees, however, show beyond doubt that Red Box extended eastward from the You Yangs well onto the basalt plains, up to $\sim 7 \mathrm{~km}$ away from the apparent edge of the granite. Darke (1841) drew a few stylised trees on the plains in these areas on his survey map, perhaps suggesting a diffuse and sparse coverage. The character of these woodlands can only be gauged by a few existing sites on roadsides, where the understorey is very similar to that of the treeless grasslands described below. It is difficult to judge how this vegetation relates to the EVC typology, but is probably referrable to Plains Grassy Woodland (Oates and Taranto 2001). Its occurrence in the grasslands reserves was patchy and minor. Given the difficulty in defining its exact extant, and the desire not to 'over plant' trees in the grasslands reserves, the restoration of this woodland type should probably be restricted to the areas immediately around the existing relict trees. This vegetation type is not pictured.

Treeless grassland. Flinders (1802 in Moloney et al. 2006) was the first to describe the Werribee grasslands, recording that the plains were "covered with small-blade grass but almost destitute of wood, and the soil was clayey and shallow." Batman (1835) described the plains in detail "... with scarcely any timber, and covered with Kangaroo grass eight and ten inches high. This I think is the average. Most beautiful sheep pasturage I ever saw in my life," and "beautiful plains of the best description of grass". The character and composition of the grassland vegetation is well known (Sutton 1916-17, Patton 1935, Willis 1964, Stuwe and Parsons 1977, Carr 1999). It was dominated by tussock grasses (Poaceae), particularly Kangaroo Grass Themeda triandra, Spear-grasses Austrostipa spp., and Wallaby-grasses Rytidosperma spp. (The current lack of Kangaroo grass in most 'native' paddocks in the study area is likely a management artefact, as most roadsides across the area support this species). Between the tussocks grew a diversity of other plants, notably broad-leaved native herbs, including many daisies (Asteraceae), geophytes (Lileacae, Orchidaceae), and some deep-rooted perennial sub-shrubs (such as Pimelea spp.). The areas mapped here as Treeless Grassland also encompass numerous small stony knolls, which are the result of uneven lava surfaces. These areas are often too small to show at the scale of mapping. Today, these differ from the grassland plains in supporting a few shrubs, such as Acacia paradoxa and Bursaria spinosa. A few early sources described shrubs or bushes on the plains (e.g. Fleming 1803), but it is not clear whether these were only on stony areas. The shrubs may have been large shrubs such as Sweet Bursaria Bursaria spinosa or Acacia spp., still common on rocky rises; smaller species such as Tree Violet Melycitus dentatus or possibly very small shrubs still present in the treeless grassland areas such as Maireana spp. and Pimelea spp. The grassland vegetation is referrable to the EVC Plains Grassland. It is listed under the EPBC Act as 'Natural Temperate Grassland of the Victorian Volcanic Plain', and under the Flora and Fauna Guarantee (FFG) Act 1988 as 'Western (Basalt) Plains Grassland Community'. The stony knolls are referrable to the EVC Stony Knoll Shrubland. Restoration of grassland vegetation with trees is inappropriate, although many small woody shrubs may be considered. Treeless grassland vegetation is pictured in Figure 5, and small shrubs in Figure 6.

Non-eucalypt woodlands of 'Oak and Honeysuckle'. Many areas now devoid of trees once supported open woodlands of She-oaks (both Drooping She-oak Allocasuarina verticillata and Buloke Allocasuarina luehmannii) and 'Honeysuckle' (Banksia marginata). For example, Hoddle (183?) described the plains of Tarneit as "broken by ridges of trap, moderately timbered with Honeysuckle and She oak." There is evidence that these stands of trees often occurred in discrete patches and clumps. Batman (1835) "passed a small forest, about two miles in length, of she-oak; about eight or ten to the acre ${ }^{1}$, and from twelve inches downward in size" Colbert (1855) described "scattered clumps of timber" near Balliang Creek. Hoddle (1850) described the Plains around Wyndham Vale as "open plains lightly timbered with she oak". Campbell (1906) describes Oaks too, "isolated clumps of which brave the wind and stand out on the plain". Oaks and Honeysuckles are also frequently used as lot corner markers (Darke 1839a, b, 1840, 1841, before 1858, undated). This vegetation has now become extremely rare locally. Oak and Honeysuckle woodland evidently once occurred on flat to undulating heavy-soil plains (most evidence for Buloke Allocasuarina luehmannii, some evidence for Honeysuckle), and also on stony rises (most evidence for Drooping She-oak Allocasuarina verticillata, some evidence for Honeysuckle); suggesting that two rather different ecological entities are included here, one on stony rises, one on plains (discussed further below). The scant evidence suggests that the lower storey of this vegetation closely resembled the open grassland and stony knoll vegetation respectively; indeed many areas which apparently once supported these woodlands are now recognised and mapped as the EVCs Plains Grassland or Stony Knoll Shrubland (Growth Areas Authority 2010a-d). Numerous historic sources (mostly parish plans not cited here) suggest that these vegetation types have disappeared from much of lowland Victoria, and their decline is worthy of further study. These non-eucalypt woodlands are probably underrepresented in Figure 2, given their frequent mention in comments on plans, without any further evidence from other sources. These areas of former non-eucalypt woodland should be a priority for restoration; given their depletion and the fact that their former character probably provided resources for animals (cones, nectar) that are now largely absent from the local landscape. Many small clumps of woodland may have disappeared without trace. It is likely that inspection of all areas on ground may reveal the presence of unnoticed stumps, leaving open the hope that some further areas of non-Eucalypt woodland can be identified. Figure 7 shows Bulokes (Allocasurina luehmannia) growing on the plains and Figure 8 shows a Honeysuckle (Banksia marginata) growing on a stoney rise.

Open wetlands. Flinders (1802; in Moloney et al. 2006) described the Werribee Plains from the You Yangs as a "low plain where the water appeared frequently to lodge". Similarly, Grimes (1803) noted

\footnotetext{
${ }^{1}$ i.e. roughly $20 \mathrm{~m}$ between trees.
} 
that "there are marks of water laying much on these plains." Howitt (1855) described that after rain the "plain underfoot was soon one universal pool". Heavy rains in 2010-11 again illustrated that water pools readily on the plains. Ephemeral wetlands (vernal pools) large and small are still so numerous it is difficult to map the smaller ones. Depending on their hydrological regime, treeless wetlands support a range of plants, with some rarely-inundated sites barely distinguishable from the surrounding grasslands; others supporting a sward of Common Tussock-grass Poa labillardierei; some supporting Tangled Lignum Muehlenbeckia florulenta or Barren Cane-grass Eragrostis infecunda. The wetlands require a number of EVCs to adequately describe their diversity. The most prominent include Lignum Wetland, Ephemeral Drainage Line Grassy Wetland, Cane Grass Wetland, and Plains Grassy Wetland (DSE 2009b). This vegetation type is not pictured.

Treed wetlands. The more substantial, deeply and/or frequently inundated wetlands support River Red Gum Eucalyptus camaldulensis, frequently above large expanses of Barren Cane-grass Eragrostis infecunda and clumps of Tangled Lignum Muehlenbeckia florulenta and a range of herbs. These treed wetlands are curiously absent from some plans that show forest boundaries (e.g. Darke 1840, 1841). Howitt (1855), trying to find shelter while passing between Geelong and Werribee in 1854 "descried a few trees some couple of miles off" but "to our consternation we found, on arriving at them, that these trees grew in a great swamp." Campbell (1905) states that “...on the plain in curious gnarled clumps stand E. rostrata [now E. camaldulensis] with fine white barrels." Even the most substantial and long-inundated treed wetlands on the Werribee Plains are to some degree ephemeral, and presumably always have been (Nixon (1859) labels one "Dry some years past"). Treed wetlands are generally assignable to the EVCs Red Gum Swamp or Lignum Wetland (DSE 2009b). Figure 9 shows a treed wetland in its context on the Werribee Plains.

\section{Discussion}

\section{The origins of the patterns}

Why did trees occur in some places, but not others? The reasons for treelessness in lowland grasslands have long been discussed, in southern Australia (Sutton 1916-1917, Patton 1935, Willis 1964, Geraghty 1971, Morcom and Westbrooke 1998, Jones 1999, Gammage 2011) and worldwide (e.g. Coupland 1979). It is generally agreed that moisture stress excludes trees. This is a function not of rainfall alone, but also the soil. Soils with fine particles, such as those clays formed on recent basaltic flows, make it physiologically difficult for plants to access water (at least during some critical times of the year) and are antagonistic to woody plant growth in low-rainfall areas. Soil cracking and shrinking in summer presumably exacerbates drought stress (Willis 1964). The occasional presence of trees in lowland grasslands is generally attributed to local factors (rockiness, small depressions, etc) subtly alleviating moisture stress.

There are relatively few experimental studies that directly link soil properties with treelessness, however one relevant study examined soil properties along a transect running from naturally treeless grassland to Grey Box forest (Rockbank to Eynesbury; within the current study area, Geraghty 1971). A link between soils and treelessness was reported; with Grey Box forest restricted to soils with quartz sand or pebbles, which are able to ameliorate the effects of the clays. Geraghty (1971) noted that this quartz was not basalt-derived, but was probably brought in by wind or (more likely) floodwaters associated with landscape reconfiguration brought about by the formation of the tectonically-controlled depression known as the Port Phillip Sunkland. This depression encompasses the lowlands of Melbourne, and is bounded in the study area by the Rowsley fault, beyond which the Brisbane Ranges and the hills of Ballan and Bacchus Marsh rise.

It is interesting to note the current distribution of forests and grasslands in relation to the existing major water courses. The forests follow the Werribee River downstream in bands on either side (Eynesbury and Pinkerton Forests; uppercentre in Figure 2). The ancient flooding which brought quartz material onto the basalt plain presumably followed roughly the same low-lying course as the current Werribee River. It is clear, however, that the Grey Box forest was once separated from the river gorge by bands of treeless grassland. This pattern is repeated on Toolern and Parwan Creeks. These bands of grassland were 50-350 m wide, and several kilometres long (Figure 2). The historic record leaves no doubt that this pattern was evident before colonisation and is displayed on all the relevant maps (Darke 1839a, b, c, d, 1840, 1841, 1858, Hoddle 1850). Wedge (1835) describes a "belt of forest trees" before meeting the Werribee River near Exford. The treeless strips separating the "belts" of forest from the gorge warrant further investigation. They may be associated with the removal of the coarser quartz material near the gorge edges as the gorge was cut, and / or may be cultural artifacts associated with aboriginal land management.

Some authors suggest that frequent fire also contributes to the exclusion of trees from grassy landscapes, including fires lit by humans over a long period as a management tool (Morcom and Westbrooke 1998, Bredenkamp et al. 2002, Yugovic and Mitchell 2006, particularly Gammage 2011). The Werribee plains were clearly burnt regularly and extensively before colonisation: Fleming (1803) noted that the grass visible on the Werribee Plains from the top of a hill was "mostly newly burnt" in February. Hovell (1824 in Moloney et al. 2006) notes that "the grass does not appear to have grown more than two or three inches since it was burned last year". Batman (1835) described the grass on the Werribee Plains as "three feet high where it had not been burnt late in the autumn, which is the case in most parts." King (1837, in Moloney et al. 2006) notes that around Melton a "great part of herbage recently burned", and describes the Little River area as "a most arid waste; the grass had been burned off." Such fires would have inevitably affected the vegetation.

We believe that the effects of fire are less able to explain the distribution of Eucalypts than the interaction of rainfall with soil. The plains beyond the Eucalyptus tree-line were clearly occupied by woodlands of 'Oak' (Allocasuarina spp.), sometimes with Honeysuckle (Banksia marginata). Those non-eucalypt trees are generally 'less tolerant' of intense 
fire than Eucalyptus (Macaulay and Westbrooke 2003), and almost all conceivable fire regimes could not exclude the local Eucalyptus species while allowing Allocasuarina and Banksia to persist. Admittedly, frequent, low-intensity fire may be able to kill eucalypt seedlings but allow Bulokes to persist via suckering (Morcom and Westbrooke 1998); although this line of argument is less applicable to Banksia or Allocasuarina verticillata. The treeless strips noted above -between rocky gorges and forest- could not be maintained by fires without very precise and deliberate fire control. It is possible that these strips were carefully maintained for some purpose by aboriginal people; but any such purpose is now lost. The soil-related reasons discussed above for the absence of Eucalyptus on the plains seem far more convincing.

While we doubt a major role of burning in regulating Eucalypt distribution, it may have had a more important role in relation to Allocasuarina and Banksia. These species can, under the right conditions, form dense stands. Despite this, the historic record confirms that they were present as woodlands in clumps and patches. For example, Batman (1835) described a discrete patch of She-oak forest at a density of "about eight or ten to the acre". Fire may once have been an important factor in preventing their local proliferation; with these species persisting in places where fire was less regular and/or less intense. The pattern of Oak and Honeysuckle distribution may well have been influenced by aboriginal burning. Some authors (notably Gammage 2011) argue that aboriginal people deliberately created clumps and lines of trees to assist hunting. This is compatible with, but unproven by, the evidence for the Werribee Plains.

On the largely treeless plains, it would seem that Drooping She-oak (Allocasuarina verticillata) was particularly prominent on stony rises (Anonymous (1845) described "...ridges timbered lightly with she-oaks"), which may have provided some degree of fire-protection. In contrast, Buloke (Allocasuarina luehmannii) was probably more prominent on the non-rocky plains, where it could survive fires by suckering, thus forming the clumps mentioned above (Figure 7). Unfortunately, the evidence for this patterning is complicated by the fact that the term "oak" was used freely in the nineteenth century to describe both Allocasuarina species (Morcom and Westbrooke 1998). Current observations (locally and elsewhere in Victoria) do, nonetheless, hint at a separation of the two species between the rises (Drooping She-oak) and the low plains (Buloke). The position of Banksia marginata on the plains is less clear. Records are located on stony rises (Figure 8), volcanoes and on non-rocky plains, but this species is so depleted that it is difficult to make any judgement on its ecological preferences without further research. Emphasis is given here to the nonEucalypt species' distribution on the plains beyond the Eucalyptus stands; but these species were probably once also present within the 'Grey Box Forest', where fire intensity was presumably relatively low. Both Allocasuarina species still occur there.
After 1835, the factors shaping the vegetation changed abruptly. While the fundamental ecological processes related to climate, soils and competition continued; new and overwhelmingly powerful forces changed the vegetation markedly, to produce the largely-cleared landscape we see today. The most obvious of these changes to affect tree distribution was the cutting of timber. The removal of discrete 'chunks' of Grey Box Forest, often following the edges of paddocks or properties, is an obvious result. Less obvious is the cutting of Allocasuarina species from the plains beyond the forests. There is some evidence that She-oak woodlands were preferentially removed for firewood (Howitt 1855, Hately 2010). Banksia woodlands presumably suffered a similar fate, but their demise may have been hastened by their palatability to sheep.

\section{Conclusions}

We hope that the data presented here will help illuminate Melbourne's relationship with the natural environment. There has been renewed interest recently in how natural geography has shaped Melbourne (e.g. Moloney et al. 2006, Boyce 2010), and it is clear that the presence of the grasslands was a major reason for Melbourne's existence, and a major influence on its development. This study should add much-needed detail to that narrative. The locations of land claims, homesteads, tracks and roadways may all be better understood with reference to the very fine-scale vegetation patterns revealed here.

We also hope that our findings will help us manage and plan for future changes to the landscape. One of the main motivations for this study was to inform ecological restoration. Historical vegetation maps are only one ingredient in a program of ecological restoration. Restoration also includes philosophical, technical and social considerations.

The technical challenges of restoration are significant. The 'template' presented here only tells the story of tree distributions. Restoration will require a more subtle understanding of small-scale spatial and temporal patterning in non-woody plants. It will also require technological knowledge about how to restore these systems efficiently.

Using historic maps as guides for restoration is also fraught by non-technical difficulties of interpretation. The most difficult problem is that it may be impossible to distinguish stable patterns from transient patterns; and culturally created boundaries from physically determined boundaries. There is a risk of considering the patterns of the mid-nineteenth century to be somehow sacrosanct; when they may really have been in flux, and may not represent the vegetation configuration which best conforms to the underlying physical and ecological drivers. The most sensible response to this seems to involve being explicit about our interest in the historic values we seek to preserve and re-create; admitting that in the absence of a better template, the 'pre-1750' is 
a practical alternative that we know was the home of the vanishing 'values' we seek to protect; and lastly, by assessing the long-term success or failure of restoration attempts which may eventually reveal subtle physical constraints we do not yet understand.

\section{Acknowledgements}

We thank Frances Overmars (Pinkerton Landcare and Environment Group), Dr John Morgan (Latrobe University), Matt White (DSE) and Colleen Miller (Western Melbourne Catchment Network) for useful discussions and for pointing us to several useful references. We thank Dr David Duncan (DSE) for comments on an early draft. We also thank Bryan Campbell for permission to use the diary of A.G. Campbell. Photographs were kindly provided by Maarten Hulzebosch (Figure 6) and Damien Cook (Australian Ecosystems Pty Ltd, Figure 7).

\section{References}

Note: The early plans are unpublished documents, with incomplete and inconsistent bibliographic information: Some are anonymous, undated and/or untitled; others are copies of earlier maps. We cite them according to the surveyor (not the lithographer, etc), or as 'Anon.' if no surveyor's name was given. We date them from the date of the survey (not subsequent copying). If no survey date is given, the earliest date of copying is used, preceded by the word 'before'; others are entirely undated. The following abbreviations are used for the microfiche collections from the Public Records Office of Victoria (PROV): SP Sale Plan, FP Features Plan, RP Roll Plan, S Sydney pre-1851.

Anon. (1838) Plan of Port Phillip for Lieut. Colonel Gibbes, Collector of Customs, Sydney. National Library of Australia. MAP RM 950.

Anon. (1845) Plan of Mr James Austin's station 'Werribee Plains'. PROV RP476

Anon. (undated a) Glenmore Station. PROV RP682

Anon. (undated b) Plan of the subdivision of sections in the parishes of Cocoroc, Murtcaim, Bulban and Wurdi-Youang. County of Grant. PROV FP535.

Anon. (undated c) Plan of the parish of Tarneit in the county of Bourke. PROV FP388.

Ashby, L., Carr, G.W., Conole, L.E. \& Renowden, C. (2007) Pinkerton Forest and Bush's Paddock: flora and fauna. Ecology Australia Project: 06-71 Prepared for Western Water and Melton Shire Council.

Baker-Gabb (2002) Surveys for Plains-wanderers Pedionomus torquatus on Astrebla Downs National Park, western Queensland. Unpublished report to Environment Australia.
Batman, J. (1835) Diary: 10th May-11th June 1835. Transcribed and printed in: Harcourt, R. (2001) Southern Invasion, Northern Conquest. Story of the Founding of Melbourne. Golden Point Press, Blackburn South. pp. 143-157.

Boyce, J. (2011) 1835: The founding of Melbourne and the conquest of Australia. Black Inc., Melbourne.

Bredenkamp, G.J., Spada, F., Kazmierczak, E. (2002) On the origin of northern and southern hemisphere grasslands. Plant Ecology 163: 209-229.

Campbell, A.G. (1906) Diary: 29 $9^{\text {th }}$ July. A.J. \& A.G. Campbell Collection, Museum Victoria.

Carr, G.W. (1999) Checklist of the vascular flora of the Victorian Volcanic Plain (1997). In: Jones, R. (1999) (Ed.) The Great Plains Crash. Proceedings of a conference on the grasslands and grassy woodlands of Victoria. Victorian Institute of Technology, October 1992. Indigenous Flora and Fauna Association \& Victorian National Parks Association. pp. 91119 (Appendix 1)

Colbert, E. (1855) Agricultural reserve in the parishes of Balliang, Mouyong, Bulban, Lara \& Wurdi-Youang. PROV SP59 (also used as base map for PROV FP609)

Cook, D. \& Yugovic J. (2003) Clyde-Tooradin grassland rediscovered. The Victorian Naturalist 120: 140-146.

Coupland, R.T. (1979) The nature of grassland. In: Coupland, R.T. (Ed) (1979) Grassland ecosystems of the world. pp. 23-30. International Biological Program 18, Cambridge University Press, UK.

Cox, H.L. (1865) Port Phillip [map]. Published at the Admiralty Aug. 19th 1865 under the superintendence of Captn. G.H. Richards. National Library of Australia MAP RM 1696.

Darke, W.W. (1839a) Plan of the Parish of Pywheitjorrk in the County of Bourke. PROV S20

Darke, W.W. (1839b) Plan of the parishes of Mooradoranook in the county of Grant. PROV S35

Darke, W.W. (1839c) Plan of the parish of Djerriwarrh in the County of Bourke. PROV S15\&16

Darke, W.W. (1840) Survey of part of the River Werribee and its tributaries shewing also the lands measured for sale in its vicinity. PROV RP108 (part missing)

Darke, W.W. (1841) Survey of the present and proposed lines of road and the coast between Melbourne and Geelong shewing the intervening streams and lands measured for sale. PROV RP109.

Darke, W.W. (before 1858) Plan of the Parish of Werribee in the county of Grant PROV FP369.

Darke, W.W. (undated) Plan of the parishes of Derrimut and Maribyrnong in the county of Bourke. PROV

Department of Planning and Community Development (2009) Delivering Melbourne's newest sustainable communities. Strategic impact assessment report for the Environment Protection and Biodiversity Conservation Act 1999. Department of Planning and Community Development, East Melbourne.

Department of Sustainability and Environment (2009a) Delivering Melbourne's newest sustainable communities. Program Report. Department of Sustainability and Environment, East Melbourne.

Department of Sustainability and Environment (2009b)Wetland Ecological Vegetation classes for the Index of wetland condition. Department of Sustainability and Environment, East Melbourne.

Fleming, J. (1803) The voyage of his majesty's colonial schooner "Cumberland" from Sydney to King Island and Port Phillip in 1802-3. In: Shillinglaw. J.J. (1878) Historical Records of Port Phillip (Reprinted 1972), Heinemann, Melbourne. pp. 12-39. 
Gammage, B. (2011) The biggest estate on earth: how aborigines made Australia. Allen and Unwin, Crows Nest, New South Wales.

Geraghty, P.A. (1971) Preliminary studies on the ecology of the basalt plains west of Melbourne. A report submitted for B.Sc. (Hons), Botany School, University of Melbourne. December 1971.

Gray, C.M. \& McDougall, I. (2009) K-Ar geochronology of basalt petrogenesis, Newer Volcanic Province, Victoria. Australian Journal of Earth Sciences 56: 245-258.

Grimes, C. (1803) Port Phillip [map]. Reproduced in: Harcourt, R. (2001) Southern Invasion, Northern Conquest. Story of the Founding of Melbourne. Golden Point Press, Blackburn South. p 6.

Growth Areas Authority (2010a) Biodiversity Assessment Report (Native Vegetation): Melton-Wyndham Investigation Area Section A. Growth Areas Authority, Melbourne.

Growth Areas Authority (2010b) Biodiversity Assessment Report (Native Vegetation): Melton-Wyndham Investigation Area Section B. Growth Areas Authority, Melbourne.

Growth Areas Authority (2010c) Biodiversity Assessment Report (Native Vegetation): Melton-Wyndham Investigation Area Section C. Growth Areas Authority, Melbourne.

Growth Areas Authority (2010d) Biodiversity Assessment Report (Native Vegetation): Melton-Wyndham Investigation Area Section E. Growth Areas Authority, Melbourne.

Hare, A.G., Cas, R.A., Musgrave, R. \& Phillips, D. (2005) Magnetic and chemical stratigraphy for the Werribee Plains basaltic lava flow-field, Newer Volcanics Province, southeast Australia: implications for eruption frequency. Australian Journal of Earth Sciences 52: 41-57.

Hateley, R. (2010) The Victorian Bush, its 'original and natural' condition. Polybractea Press, South Melbourne.

Higgs, E.S. (1997) What is good ecological restoration? Conservation Biology 11: 338-348.

Hoddle, R. (183? date illegible) Plan of the proposed county of Bourke, District of Port Phillip, compiled from actual survey. PROV RP12A

Hoddle, R. (1850) Plan of ten allotments of land marked in the parishes of Mooradoranook and Werribee, County of Grant. PROV S14

Howitt, W (1855) Land, labor and gold: or two years in Victoria, with visits to Sydney and Van Diemen's Land, Longman, Brown, Green and Longmans. London.

Jones, R. (1999) Natural and human influences on the distribution and extent of Victorian lowland grasslands. In: Jones, R. (1999) (Ed.) The Great Plains Crash. Proceedings of a conference on the grasslands and grassy woodlands of Victoria. Victorian Institute of Technology, October 1992. Indigenous Flora and Fauna Association \& Victorian National Parks Association. pp. 19-40.

Lunt, I.D. (1991) Management of remnant lowland grasslands and grassy woodlands for nature conservation: a review. The Victorian Naturalist 108: 56-66.

Macaulay, L. \& Westbrooke, M. (2003) Guidelines for the management and rehabilitation of the Wimmera buloke woodlands of western Victoria. Centre for Environmental Management, University of Ballarat.

McDougall, K. (1987) Sites of Botanical Significance in the Western Region of Melbourne. Western Region Commission Incorporated and Department of Conservation, Forests and Lands, Victoria.

McDougall, K. (2008) Evidence for the natural occurrence of treeless grasslands in the Riverina region of south-eastern Australia. Australian Journal of Botany 56: 461-468.
Moloney, D., Rowe, D. \& Jellie, P. (2006) Shire of Melton Heritage Study, Stage 1. Shire of Melton.

Morcom, L.A., Westbrooke, M.E. (1998) The Pre-Settlement Vegetation of the Western and Central Wimmera Plains of Victoria, Australia. Australian Geographical Studies 36: 273288.

Morgan, J.W. \& Lunt, I.D. (1999) Effects of time-since-fire on the tussock dynamics of a dominant grass (Themeda triandra) in a temperate Australian grassland. Biological Conservation 88: 379-386.

Nixon, T. (1859) Country lots, parishes of Balliang and Mouyong, County of Grant. PROV SP37 (also used as base map for PROV FP240)

Oates, A. \& Taranto, M. (2001) Vegetation mapping of the Port Phillip \& Westernport region. Department of Natural resources and Enviornment, Arthur Rylah Institute for Environmental Research, Heidelberg.

Patton, R.T. (1935) Ecological studies in Victoria. Part IV- Basalt plains association. Proceedings of the Royal Society of Victoria 48: 172-191.

Powell, J.M. (1970) The public lands of Australia Felix: settlement and land appraisal in Victoria, 1834-91 with special reference to the western plains. Oxford University Press, Melbourne.

Rosengren, N. (1986) Sites of Geological and Geomorphological Significance in the Western Region of Melbourne. Department of Geography, University of Melbourne for Department of Conservation, Forests and Lands, Arthur Rylah Institute, Ecological Inventory and Evaluation Section.

Rosengren, N. (1999) Geology and geomporphology of Victoria's grassland regions. In: Jones. R. (1999) (Ed.) The Great Plains Crash. Proceedings of a conference on the grasslands and grassy woodlands of Victoria. Victorian Institute of Technology, October 1992. Indigenous Flora and Fauna Association \& Victorian National Parks Association. pp. 7-10.

Sinclair, S.J. (2008) Native grassland at Safety Beach, Mornington Peninsula, Victoria. The Victorian Naturalist 124: 132-149.

Stewart, G. (1977) The Newer Volcanics lava field between Deer Park and the Werribee River. Geological Survey of Victoria 1977/26.

Stuwe, J. \& Parsons, R.F. (1977) Themeda australis grasslands on the Basalt Plains, Victoria: Floristics and management effects. Australian Journal of Ecology 2: 67-476.

Sutton, C.S. (1916-1917) A sketch of the Keilor Plains flora. The Victorian Naturalist 33: 112-143.

Watkinson, A.R., Ormerod, S.J. (2001) Grasslands, grazing and biodiversity: editors' introduction (to special issue). Journal of Applied Ecology 38: 233-237

Wedge, J.H. (1835) Field book. State Library of Victoria [available online: www.slv.vic.gov.au] MS10768.

Willis, J.H. (1964) Vegetation of the basalt plains in western Victoria. Proceedings of the Royal Society of Victoria 77: 397418.

Woodgate, P.W., Peel, W.D., Ritman, K.T., Coram, J.E., Brady, A., Rule, A.J. \& Banks, J.C.G. (1994) A study of the old-growth forests of east Gippsland. Department of Conservation and Natural Resources, East Melbourne, Victoria.

Yugovic, J. \& Mitchell, S. (2006) Ecological review of the KooWee-Rup Swamp and associated grasslands. The Victorian Naturalist 123: 323-334.

Manuscript accepted 16 April 2012 


\section{Appendix 1 Photographs}

The following photographs have been selected to show what the vegetation of the Werribee Plains may have looked like in its pre-colonial state. Photographs have been selected which typify most of the vegetation types mentioned in the text. Places with mature vegetation structure, few weeds and no human infrastructure have been preferred. All are taken within the study area, expect Figure 7, which was taken further west (near Dundonnell), because no vegetation representative of Honeysuckle or Oak on stony rises could be found closer. All of these photographs show places which are now rare relicts; most of the Werribee Plains is today agricultural or urban in character.

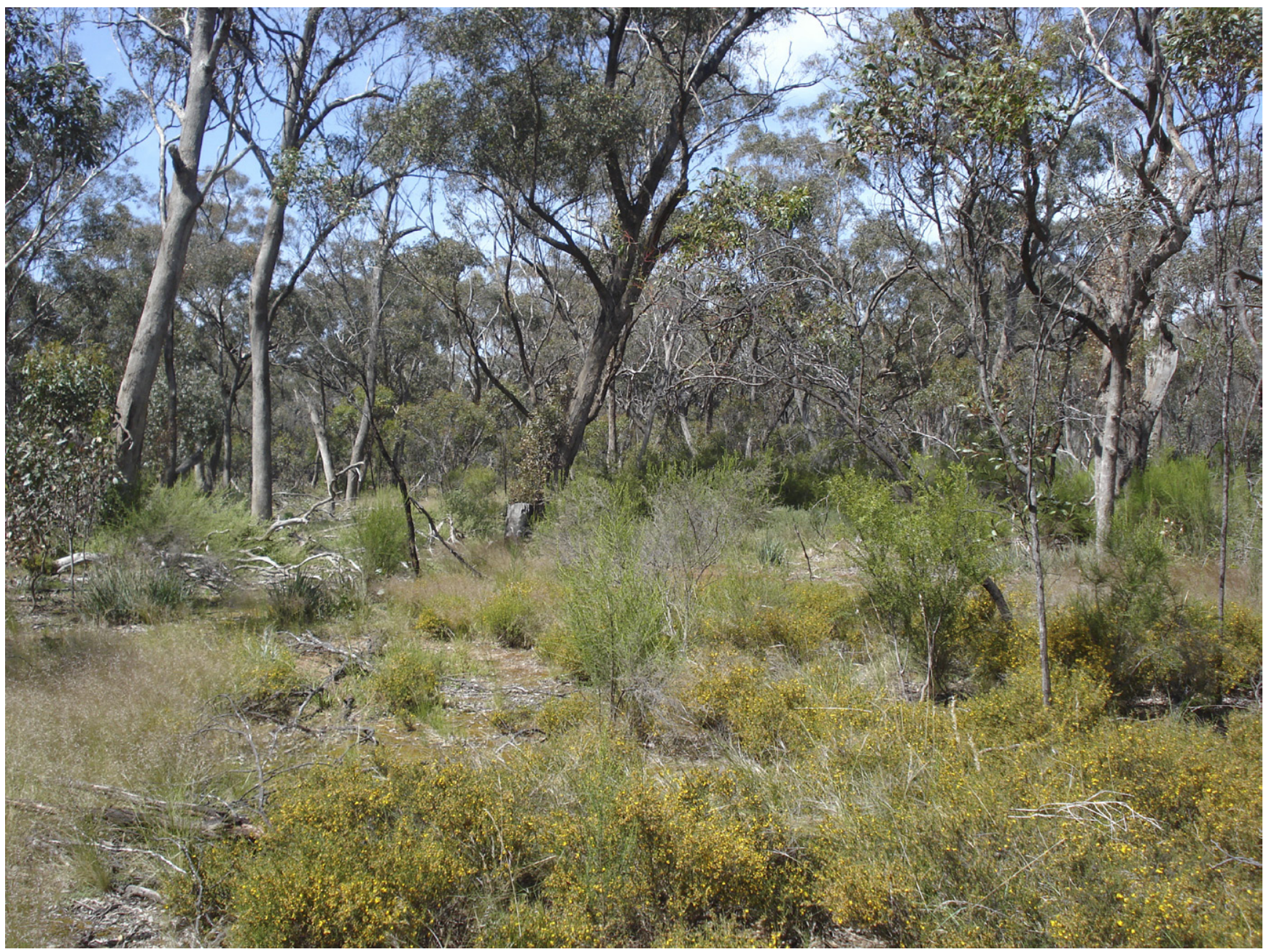

Fig. 4. Forest dominated by Grey Box (Eucalyptus microcarpa), in Eynesbury Forest, within the study area. Note that the ground layer is sparsely grassed. Flowering plants of Eutaxia microphylla are visible in the foreground. 
Fig. 5. Treeless Grassland, near Manor within the study area, photographed in Spring when the herbs are flowering and the summergrowing dominant grass Themeda triandra is in early growth. The flowers which are most prominent include Leptorhynchos squamatus (yellow) Goodenia pinnatifida (yellow), and Convolvulus angustissimus (pink).

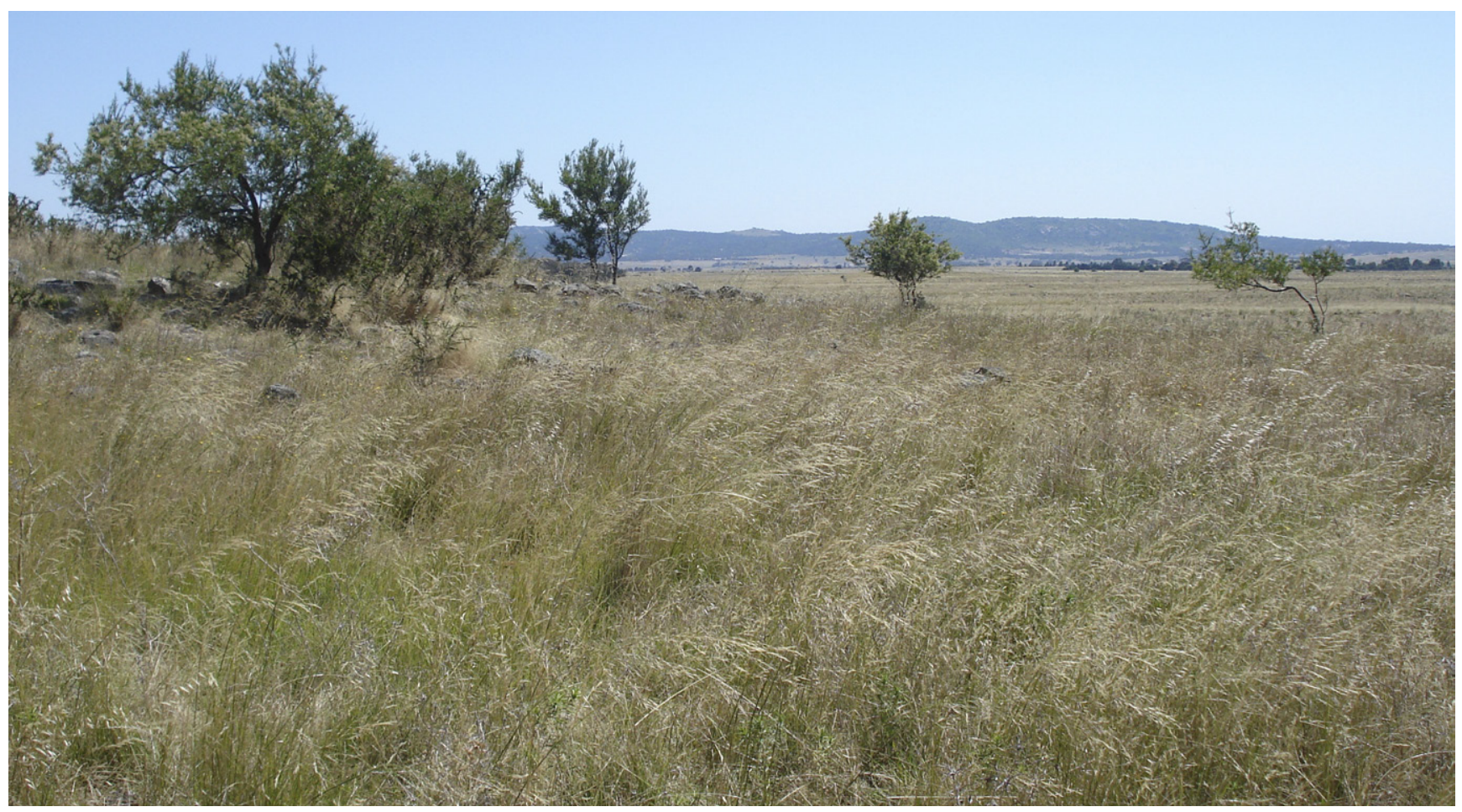

Fig. 6. Shrubs on a small stony rise within open grassland, taken at Manor, within the study area. The shrubs are Bursaria spinosa and Acacia paradoxa. The dominant grass in the foreground is Austrostipa bigeniculata. 


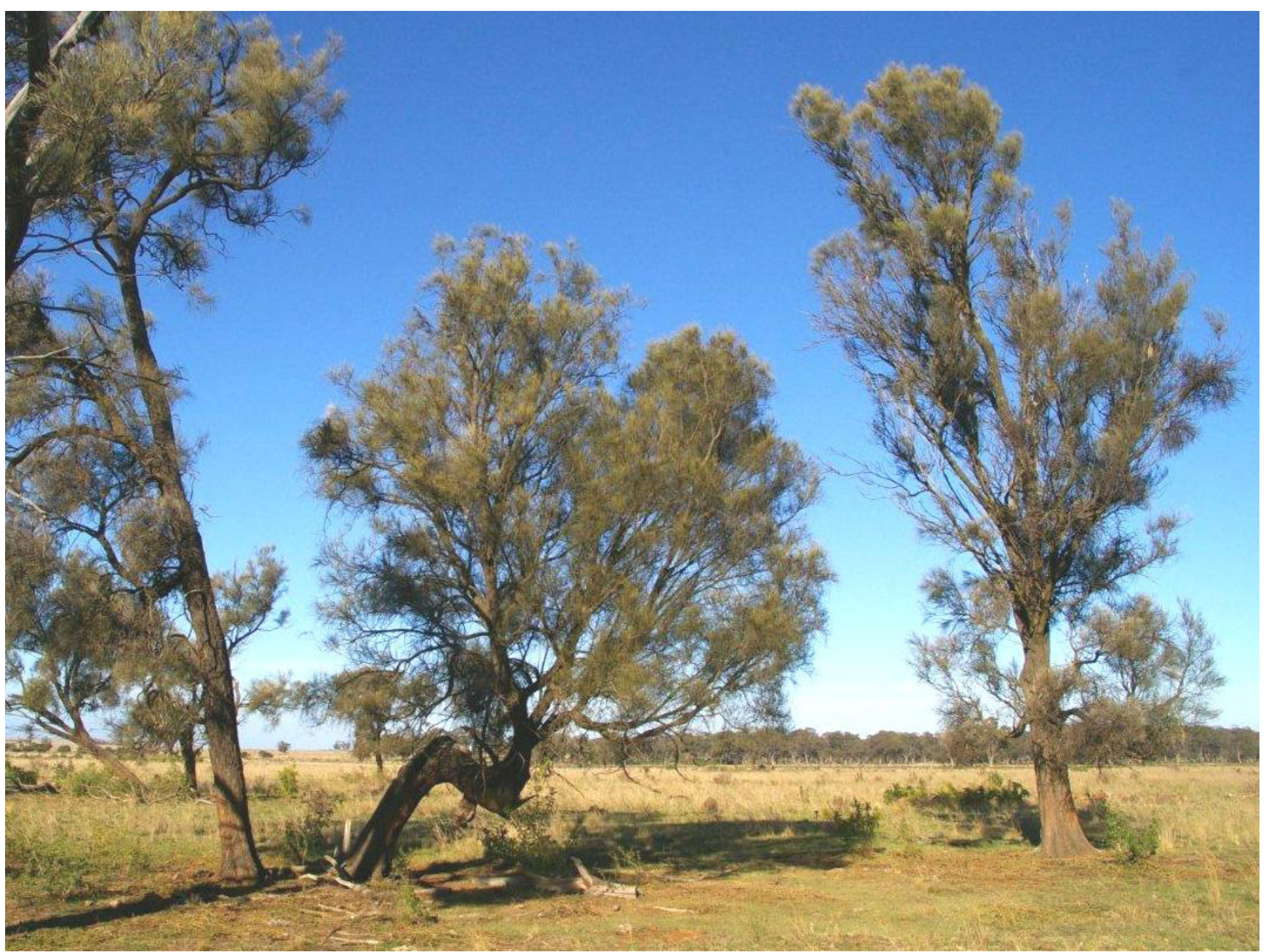

Fig. 7. Non-eucalypt woodland of 'Oak'. Here, Allocasuarina luehmannii grows on the plains near Exford, within the study area. Note that the discrete boundary of the Eucalyptus microcarpa forest is visible in the distant background. Photographed by Maarten Hulzebosch. 


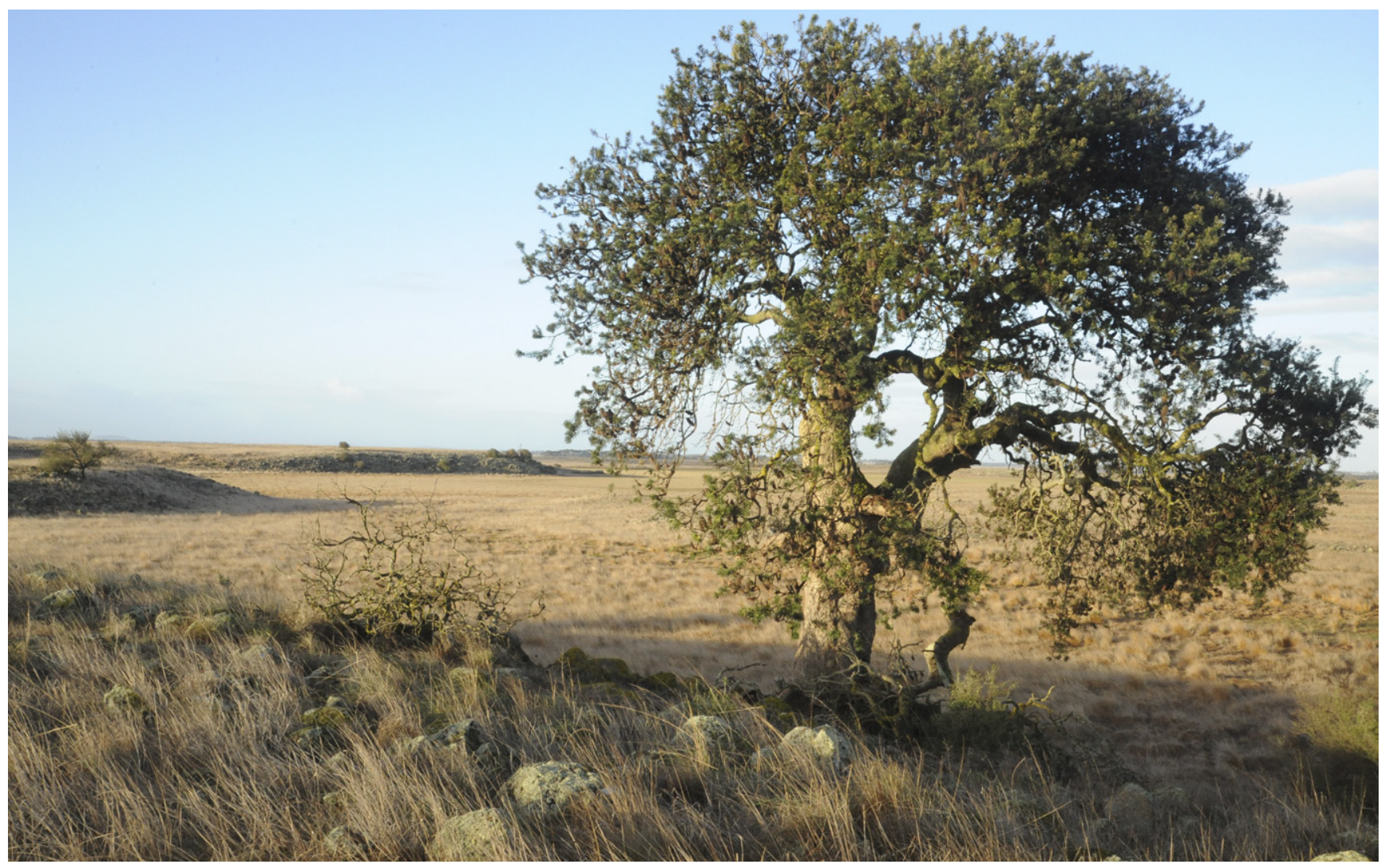

Fig. 8. Non-eucalypt woodland of 'Honeysuckle'. Here, a single individual Banksia marginata remains, growing on a stony rise. No woodlands on stony rises could be photographed within the study area. This photograph was taken further west, near Dundonnell. Photographed by Damien Cook.

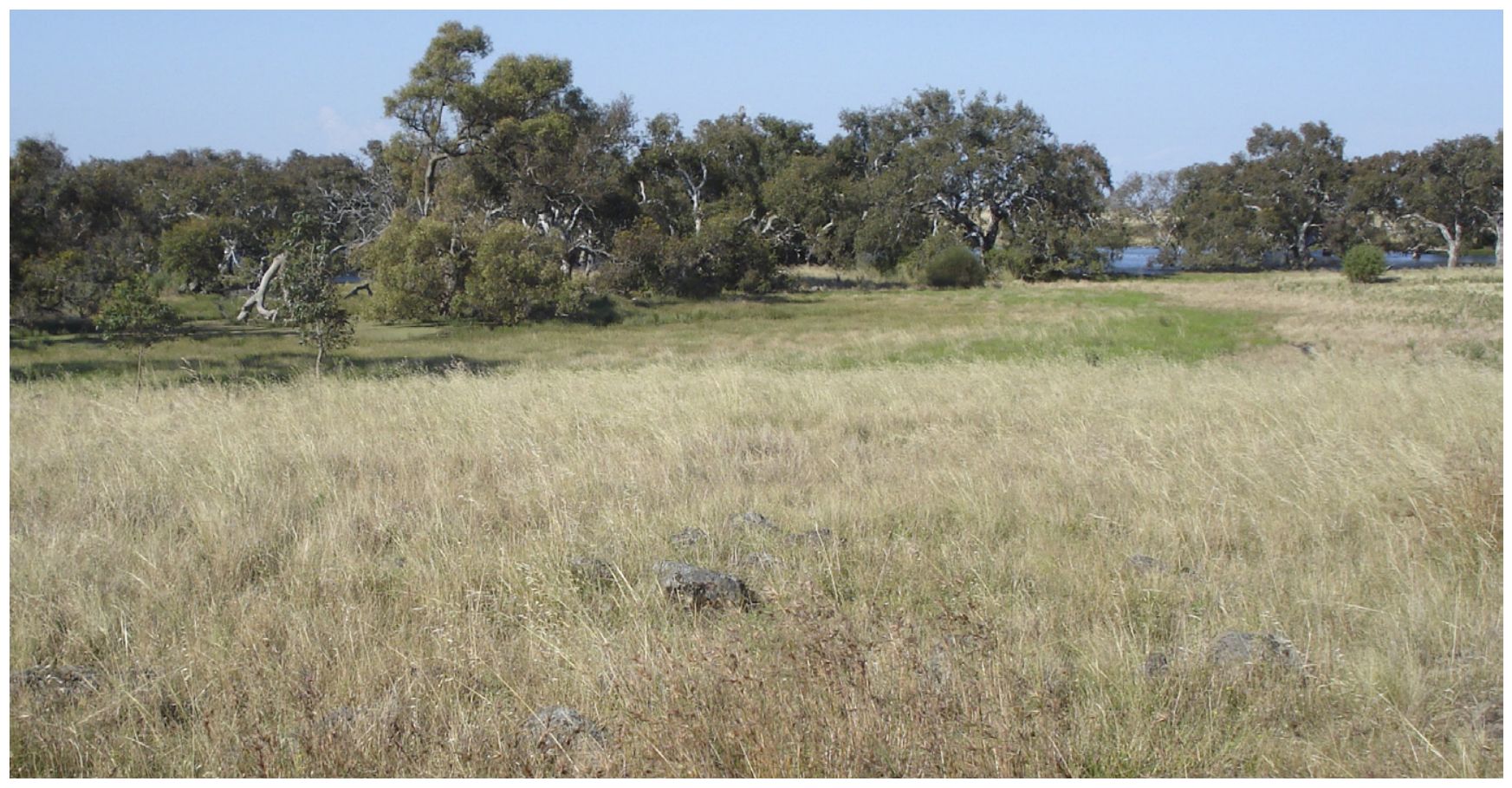

Fig. 9. Treed Wetland. Grassland dominated by Themeda triandra (foreground) grows on the high ground at front. In the lower ground at the rear, mature trees of Eucalyptus camaldulensis grow in a wetland, with a lower layer of Eleocharis acuta and patches of open water. This photograph was taken at Richmond's Swamp, within the study area. 